\section{PEPPERDINE \\ UNIVERSITY}

Journal of the National Association of

Administrative Law Judiciary

$10-15-2012$

\title{
Disabled Students' Rights of Access to Charter Schools Under the IDEA, Section 504 and the ADA
}

Robert A. Garda Jr.

Follow this and additional works at: https://digitalcommons.pepperdine.edu/naalj

Part of the Administrative Law Commons, Civil Rights and Discrimination Commons, Disability Law Commons, and the Education Law Commons

\section{Recommended Citation}

Robert A. Garda Jr., Disabled Students' Rights of Access to Charter Schools Under the IDEA, Section 504 and the ADA, $32 \mathrm{~J}$. Nat'I Ass'n Admin. L. Judiciary Iss. 2 (2012)

Available at: https://digitalcommons.pepperdine.edu/naalj/vol32/iss2/3

This Article is brought to you for free and open access by the Caruso School of Law at Pepperdine Digital Commons. It has been accepted for inclusion in Journal of the National Association of Administrative Law Judiciary by an authorized editor of Pepperdine Digital Commons. For more information, please contact bailey.berry@pepperdine.edu. 


\section{Disabled Students' Rights of Access to Charter Schools Under the IDEA, Section 504 and the ADA}

By Robert A. Garda, Jr.*

\section{$\underline{\text { TABLE OF CONTENTS }}$}

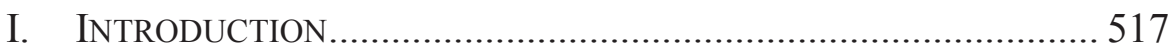

II. ACCESS RightS UNDER IDEA ............................................... 520

III. ACCESS RightS UNDER SECTION 504 AND

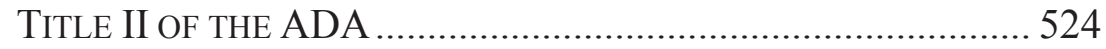

A. Schools Must Provide a FAPE On-Site Unless Doing So is an

Undue Burden or Fundamentally Alters the Educational

Program ................................................................... 524

B. Fundamental Alterations and Undue Burdens in Schools .... 533

1. Undue Financial Burden .................................................... 533

2. Fundamental Alteration.................................................. 537

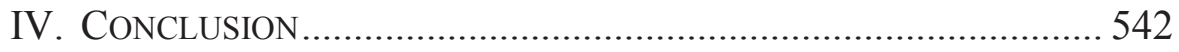


Charter schools are under increasing attack for denying admission to disabled students. But traditional schools also turn away disabled students, often preventing them from attending schools in their neighborhood or within their district. This Article discusses when a school is permitted under federal disability law to deny admission to a disabled student. After nearly four decades of special education jurisprudence and regulatory guidance, the circumstances under which a student with a disability may be denied admission to a particular school are still remarkably unclear. This Article first discusses the "zero-reject" principle underlying the Individuals with Disabilities Education Act and concludes that it does not grant a right of access to a particular school. The Article next explains the complicated interplay between Section 504 of the Rehabilitation Act and the Americans with Disabilities Act and argues that combined, these antidiscrimination statutes compel particular schools to create special education programs to serve disabled students unless it is unduly burdensome or fundamentally alters the nature of the school. The Article concludes by surveying the regulatory guidance and case law regarding what constitutes a fundamental alteration and an undue burden that may justify denying admission to disabled students.

\section{INTRODUCTION}

There are roughly 5,500 charter schools educating over $2,000,000$ students in the United States, and those numbers are expected to grow. ${ }^{1}$ Debate rages over whether charter schools are

* Fanny Edith Winn Distinguished Professor, Loyola University of New Orleans College of Law. I would like to thank Eden Heilman for her thorough and insightful review of an early draft of this article. I am also appreciative of the valuable feedback I received at the symposium "Examining the IDEA in Theory and Practice" sponsored by Loyola Law School, Pepperdine Law School and Southwestern Law School and at the Disability Law Section Rountable at the Southeast Association of Law Schools. Finally, special thanks go to Anna Boureiko for her invaluable research assistance and Professor Mark Weber for acting as a sounding board when this article was in the conception stage.

1 Schools Overview, NAT'L AlLiAnce FOR PUB. CHARTER Sch., http://www.publiccharters.org/dashboard/schools/page/overview/year/2012 (last 
superior to traditional public schools, ${ }^{2}$ but one thing is certain: many charter schools under-enroll students with disabilities. ${ }^{3}$ For example, in New Orleans - the district with the highest percentage of students attending charter schools - students with disabilities comprise 13\% of the student population in traditional schools but only $9 \%$ of the population in charter schools. ${ }^{4}$ The enrollment of disabled students in charter schools in Los Angeles Unified School District-the district with the largest number of students enrolled in charter schools - is also "disproportionately low." A similar disparity exists nationwide. The General Accountability Office found that disabled

visited October 23, 2012); U.S. DEP'T OF EDUC., THE EVALUATION OF CHARTER SCHOOL IMPACTS: FINAL REPORT 1 (June 2010), available at http://ies.ed.gov/ncee/pubs/20104029/pdf/20104029.pdf (noting that charter schools are poised for "another period of significant growth . . ..") [hereinafter EVALUATION OF CHARTER SCHOOL IMPACTS].

2 See Nat'l Alliance for Pub. Charter Sch., Measuring Charter PERformance: A ReVIEW of Public Charter School ACHIEVEMENT Studies 2-6 (6th ed. 2010) (concluding that charter school achievement results are mixed); EVALUATION OF CHARTER SCHOOL IMPACTS, supra note 1, at 3, 75-77 (summarizing research regarding charter schools' effect on student achievement). Compare CTR. FOR RESEARCH ON EDUC. OUtCOMES, STANFORd UnIV., MulTiPle Choice: Charter School Performance In 16 StATes 50 (June 2009), available at

http://www.btu.org/sites/default/files/research/credo_standrod_charter_school_perf ormance_full.pdf (concluding traditional school students outperform cohorts at charter schools), with JOAN HERMAN ET AL., EVALUATION OF GREEN DOT'S LOCKE TRANSFORMATION PROJECT: FINDINGS FOR COHORT 1 AND 2 STUDENTS 38 (2012), available at http://www.cse.ucla.edu/products/reports/R815.pdf (concluding charter school students outperform cohorts at traditional public schools).

3 U.S. GOV'T ACCOUNTABILITY OfFICE, GAO-12-543, CHARTER Schools: Additional Federal AtTention NeEded to Help Protect Access FOR STUDENTS WITH DISABILITIES 6 (2012), available at http://blogs.edweek.org/edweek/charterschoice/CharterReportGAO.pdf; Robert A. Garda, Jr., Culture Clash: Special Education in Charter Schools, 90 N.C. L. REV. $655,681-85$ (2012) (summarizing national and local reports of under-enrollment of students with disabilities in charter schools).

4 Teaching in New Orleans, TEACHNOLA, http://teachnola.ttrack.org/AboutUs/TeachinginNewOrleansBatonRouge.aspx (last visited Oct. 23, 2012); Larry Abramson, Does New Orleans Welcome Disabled Students?, NPR (Nov. 15, 2011), http://www.npr.org/2011/11/15/142138523/.

5 OfFice of the IndeP. MONitor, Pilot Study of Charter Schools' COMPliAnCE WITH THE MODIFIED CONSENT DECREE AND THE LAUSD SPECIAL EducAtion Policies AND PROCEDURES ii, 11-14 (June 5, 2009), available at http://oimla.com/pdf/20090605/PilotCharterSchool.pdf. 
students represent $8 \%$ of the population in charter schools, but $11 \%$ of the population in traditional schools. ${ }^{6}$ The underrepresentation of disabled students has brought to light a controversial, and surprisingly unanswered, question in disability law: whether any school, charter or traditional, may deny admission to a student based on her disability. This Article attempts to answer this apparently simple question, but finds the answer to be quite complicated.

Charter schools are public schools that exist by charter, or contract, with authorizers such as school districts, state school boards, or universities. ${ }^{7}$ Charter schools operate free from many of the local and state regulations that apply to traditional public schools. ${ }^{8}$ But charter schools must comply with the federal laws governing disabled students - the Individuals with Disabilities Education Act (IDEA), Section 504 of the Rehabilitation Act ("Section 504") 9 and Title II of the Americans with Disabilities Act (ADA). ${ }^{10}$ Because charter schools are public, students seeking admission should enjoy the exact same access rights as disabled students seeking admission to traditional public schools. But the laws are complex, overlapping, and often contradictory making their application difficult in traditional schools and particularly in charter schools. $^{11}$

${ }^{6}$ U.S. GOV'T ACCOUNTABILITY OFFICE, supra note 3, at 6.

7 There are numerous definitions of "charter schools" because of significant variations among the states. For general definitions, see 20 U.S.C. $\S$ 7221i(1) (2006) (defining charter schools for purposes of eligibility of federal grants); School Choices for Parents, ED.Gov U.S. DEP'T OF EDUC. (Jan. 14, 2009), http://www2.ed.gov/parents/schools/choice/definitions.html; About Charter Schools, NAT'L AlliANCE FOR PUB. CHARTER SCH., http://www.publiccharters.org/About-Charter-Schools.aspx; Just the FAQsCharter Schools, CENTER FOR EDUC. REFORM, http://www.edreform.com/2012/03/just-the-faqs-charter-schools/ (last visited Nov. 17, 2012).

${ }^{8}$ Garda, supra note 3, at 663-66.

${ }^{9}$ Rehabilitation Act of 1973 §504, 29 U.S.C. § 794 (2006).

${ }^{10}$ Americans with Disabilities Act (ADA), 42 U.S.C. $\$ 12101$ (2006). For discussion of the applicability of the IDEA, Section 504, and the ADA to charter schools in general, see Jay P. Heubert, Schools Without Rules? Charter Schools, Federal Disability Law, and the Paradoxes of Deregulation, 32 HARV. C.R.-C.L. L. REV. 301, 303, 315, 343-45 (1997).

11 Sean Cavanaugh \& Nirvi Shah, GAO Probes Charters on Serving Students with Disabilities, EDUC. WK. (June 19, 2012), 
This Article discusses the legal obligations of charter schools and traditional public schools to enroll disabled students under the IDEA, ADA and Section 504. Part II examines access rights under IDEA and attempts to explain how the zero-reject principle applies in light of the express provisions permitting schools to deny admission to disabled students and place them at other schools. Part III explains how the unqualified duty to provide a free appropriate public education (FAPE) under Section 504 interacts with the ADA's undue burden and fundamental alteration limits on the duty to accommodate disabled students. It concludes that a school's ability under Section 504 to provide a FAPE, by placing the student at a different school and merely maintaining financial and legal responsibility for the student, is limited by the undue burden and fundamental alteration standards in the ADA. The Article then examines how the undue burden and fundamental alteration limits have been applied by courts, hearing officers, and the Office of Civil Rights in the education context.

\section{ACCEss Rights UnDER IDEA}

At the core of IDEA is the "zero-reject" principle- no child can be denied an education because of his or her disability. ${ }^{12}$ On its face, the principle appears to prohibit an individual school from rejecting a student due to disability. But this is far from the case as IDEA expressly permits schools and Local Educational Agencies (LEAs) to deny admission to disabled students so long as the LEA ensures the student is placed at a school that provides the student a FAPE. $^{13}$

IDEA merely provides that a disabled student should be educated "as close as possible to the child's home" and "in the school that he or she would attend if nondisabled." 14 Courts unanimously

http://blogs.edweek.org/edweek/charterschoice/2012/06/gao_probes_charters_on_s erving_students_with_disabilities.html (noting that the U.S. Department of Education is planning on releasing new guidance to charter schools on their obligations to serve students with disabilities because the old guidance is outdated and unclear).

${ }^{12}$ Timothy W. v. Rochester, N.H., Sch. Dist., 875 F.2d 954, 960 (1st Cir. 1989); Thomas v. Cincinnati Bd. of Educ., 918 F.2d 618, 620 (6th Cir. 1990).

1320 U.S.C. § 1412(a) (2006).

1434 C.F.R. $\S 300.116(b)(3)-(c)(2012)$. 
agree that this language does not create a right to attend a particular school. ${ }^{15}$ LEAs do not have to provide special education and services at a particular school if placement at another school within the LEA would provide a FAPE. ${ }^{16}$ The courts do not delineate a precise standard to overcome the presumption that a student should be placed at a school he or she would attend if not disabled, but they consistently require that the LEA have a fully developed appropriate program at the non-assigned school. ${ }^{17}$ This permits districts to concentrate resources for particular disabilities at a limited number of regional schools and "cluster" students with the same disabilities at those schools instead of creating programs at each neighborhood school. $^{18}$

In the context of charter schools, this requires a charter school that is part of an LEA to admit and serve a disabled student "[u]nless the IEP ... requires some other arrangement . . .."19 Once a disabled student is admitted through the lottery to a charter school that is part of a LEA, the student's parents and Individualized Education Plan ("IEP") team, not charter school administrators, change the student's placement to another school in the LEA equipped to provide the child a FAPE. $^{20}$ The LEA, not the individual charter school, maintains legal and financial responsibility for the student. This is commensurate with traditional schools' ability to deny placement at the neighborhood school if a regional program within the district is capable of providing the child with a FAPE.

This analysis apparently does not change if the charter school is an independent LEA. On the one hand, IDEA requires that LEAs - not individual schools-make "available" a FAPE to

${ }^{15}$ White ex rel. White v. Ascension Parish Sch. Bd., 343 F.3d 373 (5th Cir. 2003).

16 Schuldt v. Mankato Indep. Sch. Dist. No. 77, 937 F.2d 1357, 1361, 1363 (8th Cir. 1991).

${ }^{17}$ See Garda, supra note 3, at 677-79 and cases cited therein.

${ }^{18}$ Flour Bluff Indep. Sch. Dist. v. Katherine M. ex rel. Lena T., 91 F.3d 689, 694 (5th Cir. 1996); White, 343 F.3d at 382.

1934 C.F.R. $\S 300.116(\mathrm{c})(2012)$.

2020 U.S.C. $\S 1414(\mathrm{~d})(1)(\mathrm{A})(\mathrm{iv}),(\mathrm{e})(2006)$; 34 C.F.R. $\S \S 300.116, .327$, .501(c); OCR Staff Memorandum, 22 INDIVIDUALS WITH DisABILITIES EDUC. L. REP. 669, 670 (July 27, 1990); Spielberg v. Henrico Cnty. Pub. Sch., 853 F.2d 256, 259 (4th Cir. 1988). 
students with disabilities ${ }^{21}$ and that every "public agency must ensure that a continuum of alternative educational placements is available to meet the needs of children with disabilities ...."22 The "available" language, combined with IDEA placing the primary locus of responsibility to provide a FAPE on the LEA, could mean that an LEA must provide a FAPE and a full continuum of placements within its schools. In other words, there may not be a right to attend a particular school, but there may be a right to attend a school in the LEA or district. But traditional LEAs often place disabled students outside of the schools they operate. IDEA specifically permits LEAs to place disabled students at state institutions ${ }^{23}$ and private schools ${ }^{24}$ as a means of providing FAPE. LEAs also place students at traditional schools they do not operate, and this practice is not questioned by courts. ${ }^{25}$ The only apparent limitation on the LEA's ability to deny admission to one of its schools and provide FAPE outside the LEA is the general provision discussed above that students should be educated as close to their home as possible and in the same school they would attend if they were not disabled.

Based on these provisions alone, an LEA may make "available" a FAPE and a full continuum of alternative placements by placing disabled students outside of LEA schools so long as it maintains financial and legal responsibility for the child's

2120 U.S.C. $\S \S 1412(a)(1), 1413(a)(1)(2006)$.

2234 C.F.R. $§ 300.115$ (2012). "Public agency" includes LEAs and charter schools. 34 C.F.R. $\S 300.33$ (2012).

2320 U.S.C. $\S 1413(\mathrm{~g})(1)(2006) ; 34$ C.F.R. $\S 300.175$, .227(a)(iv), .227(b) (2012).

2420 U.S.C. $\S 1412(\mathrm{a})(10)(B)(2006) ; 34$ C.F.R. $\S 300.145-.147, .325$ (2012).

${ }^{25}$ Hudson ex rel. Hudson v. Bloomfield Hills Pub. Sch., 108 F.3d 112, 113 (6th Cir. 1997) (child placed in public school outside of district and court held that IDEA does not require placement in a neighborhood school, but did not discuss if district must create program within the district); Oberti ex rel. Oberti v. Bd. of Educ. of Borough of Clementon Sch. Dist., 995 F.2d 1204, 1206 (3d. Cir. 1993) (child contested placement in segregated special education classroom outside district, but court only addressed segregated placement and not whether district had to create a placement within the district); Wilson ex rel.Wilson v. Marana Unified Sch. Dist. No. 6 of Pima Cnty., 735 F.2d 1178, 1180, 1184 (9th Cir. 1984) (same). 
education. $^{26}$ The "zero-reject" principle of IDEA does not prohibit an LEA from rejecting a student from its schools; it merely requires an LEA to provide an education to the child somewhere. ${ }^{27}$ Because charter schools that are LEAs have obligations commensurate with traditional LEAs, ${ }^{28}$ independent charter schools may place admitted students at another school so long as the charter school creates an IEP - the placement decision is made by the IEP team and the parents, and the charter school maintains financial and legal responsibility for the child's education. ${ }^{29}$

This apparently unfettered right to deny admission and provide FAPE at another school or LEA (i.e., "off-site") is troubling. Taken to its logical extreme, individual schools and even entire districts could contract out all special education services off-site to private schools, state schools, or schools in other LEAs, and deny admission to all disabled students. While this may not violate the letter of IDEA, it certainly violates the spirit of the law to grant disabled students access to public schools that had previously excluded them. ${ }^{30}$ It is for this reason that the ability of a particular school to deny admission to disabled students should be limited by the nondiscrimination principles of Section 504 and Title II of the ADA. Every child that is IDEA-eligible is almost certainly eligible for protections under Section 504 and Title II of the ADA, and is concurrently subject to those protections. ${ }^{31}$ As discussed in the next section, these nondiscrimination protections should limit IDEA's

${ }^{26}$ L.Y. ex rel. J.Y. v. Bayonne Bd. of Educ., 384 F. App'x 58, 61 (3d Cir. 2010), aff'g L.Y. ex rel. J.Y. v. Bayonne Bd. of Educ., No. 09-4422, 2010 WL 2340176, at *1 (D.N.J. Sep. 15, 2010).

${ }^{27}$ See supra notes $12-18$ and accompanying text (reiterating the idea that a child should be educated as close to home as possible but without providing specifics as to the school the child has a right to attend or whether the child has the right to attend any particular school of choice).

2834 C.F.R. § 300.209(c) (2012); Ariz. State Bd. for Charter Sch. v. U.S. Dep't of Educ., 464 F.3d 1003, 1009-10 (9th Cir. 2006); Thompson v. Bd. of Special Sch. Dist., 144 F.3d 574, 578-79 (8th Cir. 1998); Friendship Edison Pub. Charter Sch. v. Smith, 561 F. Supp. 2d 74, 75-76 (D.D.C. 2008).

${ }^{29}$ See supra note 18 and accompanying text; 20 U.S.C. $§ 1414(d)(2)(A)$ (2006) (LEAs must have in effect an individualized educational program "for each child with a disability in the agency's jurisdiction . ...").

30 See 20 U.S.C. $\S 1400(c)(2)(B)(2006)$.

${ }^{31}$ Mark C. Weber, A New Look at Section 504 and the ADA in Special Education Cases, 16 TEX. J. C.L. \& C.R. 1, 8-9 (2010). 
permissive stance towards denying admission to schools, or districts, and providing a FAPE off-site.

\section{ACCESS Rights Under SECTION 504 AND TitLE II OF THE ADA}

\section{A. Schools Must Provide a FAPE On-Site Unless Doing So is an Undue Burden or Fundamentally Alters the Educational Program}

Title II of the ADA and Section 504 of the Rehabilitation Act are non-discrimination statutes and have nearly identical language. Title II of the ADA provides: "[N]o qualified individual with a disability shall, by reason of such disability, be excluded from participation in or be denied the benefits of the services, programs, or activities of a public entity, or be subjected to discrimination by any such entity." 32 Section 504 of the Rehabilitation Act provides: "No otherwise qualified individual with a disability . . . shall, solely by reason of her or his disability, be excluded from the participation in . . . any program or activity receiving Federal financial assistance . . . .33 The only readily apparent difference between the two is that Title II applies to "public entities," which includes public schools, ${ }^{34}$ while the Rehabilitation Act applies to recipients of "Federal financial assistance," 35 which includes any schools receiving federal money. ${ }^{36}$ Indeed, many courts rule that schools' obligations to qualified students with disabilities are the same under both statutes, warranting only a single analysis. ${ }^{37}$

But the regulations include a key difference with respect to access rights. The ADA requires public entities to make reasonable accommodations to avoid discrimination unless they fundamentally alter the program, ${ }^{38}$ whereas Section 504 requires schools receiving

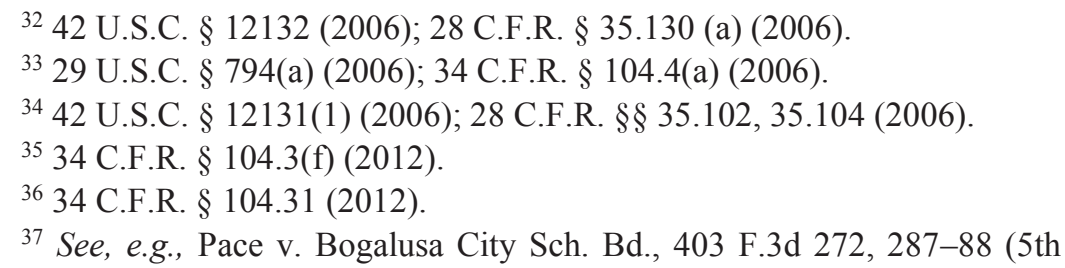
Cir. 2005); Doe v. Woodford Cnty. Bd. of Educ., 213 F.3d 921, 925 (6th Cir. 2000); Zukle v. Regents of Univ. of Cal., 166 F.3d 1041, 1045 (9th Cir. 1999); Layton v. Elder, 143 F.3d 469, 487 (8th Cir. 1998).

3842 U.S.C. $\S 12112$ (2006). 
federal funds to provide FAPE to avoid discrimination and does not include a "fundamental alteration" limitation. ${ }^{39}$ The general regulations implementing the ADA provide that covered entities must "make reasonable modifications in policies, practices, or procedures when ... necessary to avoid discrimination on the basis of disability, unless the public entity can demonstrate that making the modifications would fundamentally alter the nature of the service, program, or activity."40 Despite the regulation only mentioning "fundamental alteration," courts, hearing officers, and the Office for Civil Rights (OCR) consistently find that this means either a fundamental alteration to the essence of the program or an undue financial or administrative burden. ${ }^{41}$ Section 504 contains a similar "reasonable accommodation" standard in its general provision, ${ }^{42}$ Subpart B covering employment ${ }^{43}$ and Subpart E covering postsecondary and vocational education, ${ }^{44}$ but not in Subpart D covering elementary and secondary education. Rather, Subpart D requires schools to provide a FAPE without any limitation. ${ }^{45}$

There is confusion about whether Subpart D of Section 504 implicitly incorporates a reasonable accommodation/fundamental alteration limitation into the FAPE standard. If Title II's fundamental alteration "exception" applies to Section 504's FAPE requirement, schools would not have to provide a FAPE if the requisite services fundamentally altered the school. The OCR flatly rejected this position for three reasons. ${ }^{46}$

First, it cited to the different requirements in the different

3934 C.F.R. § 104.33(a) (2012).

${ }^{40} 28$ C.F.R. $\S 35.130(b)(7)$ (2012).

${ }^{41}$ See infra Part III.B.

4228 C.F.R. $\S 41.53$ (2012).

4334 C.F.R. § 140.12(a) (2012) (a "reasonable accommodation" is required unless it "would impose an undue hardship on the operation of its program (....").

4434 C.F.R. $\$ 104.44$ (2012).

4534 C.F.R. § 104.33(a) (2012)

${ }^{46}$ OCR Policy Letter to Zirkel, 20 InDIVIDUALS WITH DisABILITIES EDUC. L. REP. 134 (OCR 1993) (there is no "limitation of the FAPE guarantee."); Ripon Unified Sch. Dist., 46 InDIVIDUAls with Disabilities EdUC. L. REP. 82 (OCR 2006) (holding that the FAPE standard applies to educational services whereas the reasonable accommodation standard applies to non-educational services such as extracurricular activities). 
subparts of Section 504, as noted above, to conclude that Section 504, as applied to elementary and secondary schools, does not include a fundamental alteration exception. ${ }^{47}$ Second, it cited to language in the ADA stating that Title II cannot be construed to apply a lesser standard than Section $504 .^{48}$ Reading a fundamental alteration limitation into Section 504's FAPE standard would constitute such a lesser standard. Finally, it reasoned that Title II adopts the standards of Section 504 where Title II has not adopted a different standard, and Title II does not specifically address discrimination in elementary and secondary education whereas Section 504 does. $^{49}$

While this logic is sound, courts, state hearing officers, and OCR itself often apply a fundamental alteration analysis when determining what accommodations and services a school must provide for qualifying disabled students. For example, in D.R. v. Antelope Valley Union High School District, ${ }^{50}$ an orthopedically impaired student was denied her request for use of the elevator. ${ }^{51}$ Instead of utilizing the Section 504 FAPE standard-i.e. whether the requested accommodation was necessary to provide a FAPE-the court held that providing the student an elevator key was not a fundamental alteration of the school program, and the denial constituted discrimination under Section 504. ${ }^{52}$ In Tewksbury Public

47 See supra notes $42-45$ and accompanying text.
48 34 C.F.R. $\S 35.103$ (2012).
${ }^{49} 42$ U.S.C. $\S 12201($ a) $(2006)$; 28 C.F.R. $\S 35.130($ b)(7) (2012).
50746 F. Supp. 2 d 1132 (C.D. Cal. 2010).
${ }^{51}$ Id. at 1138 .
${ }^{52}$ Id. at 1132 ; see also C.C. ex rel. Ciriacks v. Cypress Sch. Dist., 56 INDIVIDUALS WITH DisABILITIES EDUC. L. REP. 295 (C.D. Cal. 2011) (failure to allow service dog was discrimination because it was not a fundamental alteration to the autism program); Sullivan v. Vallejo City Unified Sch. Dist., 731 F. Supp. 947, 960 (E.D. Cal. 1990) (applying undue burden and fundamental alteration analysis to provision of a service dog); St. Louis Dev. Disabilities Treatment Cent. Parents Ass'n v. Mallory, 591 F. Supp. 1416, 1470 n. 89 (W.D. Mo. 1984) (noting that undue financial hardship limits what services must be provided under Section 504); William S. v. Gill, 572 F. Supp. 509, 517 (N.D. Ill. 1983) (mentioning undue burden in placement decision under Section 504); Turillo v. Tyson, 535 F. Supp. 577, 587 (D.R.I. 1982) (noting that the undue burden and fundamental alteration analysis applies in placement decision under Section 504). 
Schools ${ }^{53}$ the child in a hospital school required twenty-four hour physician coverage, enhanced nursing staff, and changes to the building. ${ }^{54}$ Instead of applying a FAPE standard, the hearing officer held that these changes did not fundamentally alter the program and failure to provide them was discriminatory in violation of Section $504 .^{55}$ Even OCR has applied the fundamental alteration limitation in determining what services must be provided to disabled students. ${ }^{56}$

The confusion over whether to apply the fundamental alteration limitation of Title II of the ADA and the non-primary and secondary education subparts of Section 504 to the FAPE obligation is the result of courts, hearing officers, and OCR asking the wrong question. The appropriate question is not whether an accommodation that creates an undue burden excuses a school or district from providing a FAPE. Rather, the proper question is whether the school or district must provide the FAPE on-site.

As noted by OCR and in the Section 504 regulations, a FAPE must always be provided "regardless of the nature or severity of the person's handicap." 57 In other words, a school must always provide a FAPE even if the necessary accommodations create an undue burden or fundamental alteration. But the regulations permit entities to provide a FAPE by referring the child to another school, or another LEA, for the provision of services. ${ }^{58}$ Section 504, like IDEA, allows schools to fulfill their FAPE obligation off-site. It specifically permits recipients, which includes individual schools as well as districts, to "place a handicapped person or refer such a person for aid, benefits, or services other than those that it operates or provides

5317 Individuals With Disabilities Educ. L. Rep. 1221 (Mass. SEA 1991).

${ }^{54} I d$.

${ }^{55}$ Id.; see also Mystic Valley Reg'l Charter Sch., 40 InDIVIDUALS WITH DisABILITIES EDUC. L. REP. 275 (Mass. SEA 2004) (holding that requested accommodations for peanut allergy did not fundamentally alter the program so failure to provide them was discrimination); Cascade Sch. Dist., 37 INDIVIDUALS WITH DisABILITIES EDUC. L. REP. 300 (Or. SEA 2002) (holding that requested accommodations for peanut allergy were unduly burdensome and did not need to be provided).

56 Santa Clara Unified Sch. Dist., 53 Individuals with DisabilitieS EDUC. L. REP. 27 (OCR 2009).

5734 C.F.R. § 104.33(a) (2012).

${ }^{58}$ See id. 
as its means" of providing a FAPE. ${ }^{59}$ The Department of Education interprets Section 504 and the ADA to mean that "schools that do not offer the special education programs or facilities that may be required by a student with a disability may refer that student to another school or educational institution." 60

This seemingly unlimited right to provide a FAPE off-site means a school or district could refuse to create special education programs, contract with others to fulfill their FAPE obligations, and deny admission to all disabled students. This cannot be the case because the apparently unfettered right to place students off-site is necessarily restrained by the equal access principles and commands underlying Section 504 and the ADA. ${ }^{61}$ Both statutes require schools to provide: "the opportunity to participate in or benefit from the . . . service" which is "equal to that afforded others;" services that are not "different or separate" and are "as effective as those provided others;" and "the enjoyment of any right, privilege, advantage, or opportunity enjoyed by others." 62

The issue, then, is not whether a district or school must

5934 C.F.R. § 104.33(b)(3) (2012); see also id. $\S \S 104.33$ (c)(2), 104.34(a); U.S. Dep'T of EduC., OfFice FOR Civil Rights, Free APPROPRIATE Public EDUCATION FOR STUDENTS WITH DisABILITIES: REQUIREMENTS UNDER SECTION 504 OF THE REHABILITATION ACT OF 1973 (2010), available at http://www2.ed.gov/about/offices/list/ocr/docs/edlite-FAPE504.html (noting that a recipient may place "an individual with disabilities in another school . . . .") [hereinafter Requirements Under Section 504].

6034 C.F.R. § 104.33(b)(3) (2012); U.S. DEP'T OF EDUC., OFFICE FOR Civil Rights, Student Placement in Elementary and Secondary Schools AND Section 504 of the Rehabilitation Act and Title II of the Americans WITH DISABILITIES ACT (2010), available at http://www2.ed.gov/about/offices/list/ocr/docs/placpub.html.

${ }^{61}$ See, e.g., Se. Cmty. Coll. v. Davis, 442 U.S. 397, 410 (1979) (holding that a program needs to be modified to the extent necessary to eliminate discrimination under Section 504); Rothschild v. Grottenthaler, 907 F.2d 286, 292 (2d Cir. 1990) (same); Dopico v. Goldschmidt, 687 F.2d 644, 653 n. 6 (2d Cir. 1982) ("[S]ection 504 of the Rehabilitation Act requires some degree of positive effort to expand the availability of federally funded programs to handicapped persons otherwise qualified to benefit from them."); Sullivan v. Vallejo City Unified Sch. Dist., 731 F. Supp. 947, 958 (E.D. Cal. 1990) (holding that "a program may not be defined in a way that effectively denies meaningful access to an otherwise qualified handicapped person.").

6234 C.F.R. $\S 300.104 .4(\mathrm{~b})(\mathrm{i})$, (ii), (iv), (vii) (2012); 28 C.F.R. $\S$ 35.130(b)(1)(i), (ii), (iv), (vii) (2012). 
always provide a child a FAPE - it must and is never excused because the accommodations fundamentally alter the school or district. The real issue is whether the school or district must provide the FAPE on-site. The fundamental alteration "limitation" is actually an obligation defining what services must be provided within the school or district. ${ }^{63}$ Services that do not fundamentally alter the program must be provided on-site while only services that fundamentally alter the school can be provided off-site.

This conclusion finds strong support in case law and an OCR ruling. In Santa Clara Unified School District, ${ }^{64}$ the district had a policy and practice of not providing special education services at the Milliken Basics Elementary School. ${ }^{65}$ OCR held that the district must allow disabled students into the school

unless the student is not qualified to attend the program, and IEP or Section 504 team determines that the school is not an appropriate placement for the student, or the District can show that offering the services needed by the student would fundamentally alter the nature of the program at the school or otherwise constitute undue burden. ${ }^{66}$

Put simply, OCR held that the undue burden and fundamental alteration limitations may excuse a school from providing services

63 See 34 C.F.R. § 104.34(a) (2012) ("A recipient shall place a handicapped person in the regular educational environment operated by the recipient unless it is demonstrated by the recipient that the education of the person in the regular environment with the use of supplementary aids and services cannot be achieved satisfactorily.") (emphasis added); Wong v. Regents of Univ. of Cal., 192 F.3d 807, 817 (9th Cir. 1999) ("[t]he educational institution has a 'real obligation . . . to seek suitable means of reasonably accommodating a handicapped person and to submit a factual record indicating that it conscientiously carried out this statutory obligation."') (quoting Wynne v. Tufts Univ. Sch. of Med., 932 F.2d 19, 25-26 (1st Cir. 1991)); N.M. Ass'n for Retarded Citizens v. New Mexico, 678 F.2d 847, 855 (10th Cir. 1982) ("modification of existing programs may be required where the financial burden would not be excessive and the accommodation would enable handicapped children to realize the benefits of the State's educational program.").

6453 InDiVIDUALS With DisabiLitiEs EdUC. L. REP. 27 (OCR 2009).

${ }^{65} \mathrm{Id}$.

${ }^{66} I d$. 
on-site.

A similar line of reasoning is employed when Courts hold that Section 504 does not create a right to attend a particular school. For example, in Barnett ex rel. Barnett v. Fairfax County School Board, ${ }^{67}$ a profoundly deaf student required a cued speech program, which involves interpreter services, speech and language therapy, and resource teacher assistance. ${ }^{68}$ The Fourth Circuit denied the student's request that the cued speech program be provided at his neighborhood high school because "[r]equiring the Board to provide every hearing-impaired student with his interpreter of choice at his base school, instead of at mainstreamed but centralized locations, in [its] view would constitute a 'substantial modification' of the Board's educational programs." 69

In the charter school context, this means that charter schools must provide disabled students a FAPE on-site unless it would unduly burden or fundamentally alter the nature of the program. If, and only if, the provision of a FAPE would overly burden the school, may it then deny admission to the disabled student and place him or her somewhere else within the district (in the case of a charter that is part of an LEA) or in another district (in the case of a charter that is an LEA).

The decision to place the student at a non-assigned school can be made only after a thorough evaluation of the student ${ }^{70}$ and must be made by a group of people knowledgeable about the student, the

67927 F.2d 146 (4th Cir. 1991), cert. denied, 502 U.S. 859 (1991).

${ }^{68} \mathrm{Id}$. at 149.

${ }^{69} \mathrm{Id}$. at 155 . See also R.K. ex rel. J.K. v. Bd. of Educ., 755 F. Supp. $2 \mathrm{~d}$ 800, 808-10 (E.D. Ky. 2010) (holding that placing a full-time nurse at the neighborhood school was a "fundamental" or "substantial" change to its program because the district already offered adequate services at another nearby school), vacated, R.K. ex. rel. J.K. v. Bd. of Educ., No. 11-5070, 11-5700, 2012 WL 3525403 (6th Cir. Aug. 16, 2012); Eva N. v. Brock, 741 F. Supp. 626, 632 (E.D. Ky. 1990) (Kentucky School for the Blind was not obligated to modify its mission and programs in order to make "reasonable accommodation" to blind student who was also profoundly mentally retarded and, thus, school's refusal to accept student did not violate Rehabilitation Act), aff'd, Eva N. v. Brock, No. 90-5911, 90-5914, 1991 WL 164324 (6th Cir. Aug. 23, 1991); Pinkerton ex rel. Pinkerton v. Moye, 509 F. Supp. 107, 114 (W.D. Va. 1981) (creating a self-contained classroom at the neighborhood school involved "substantial modifications" under Section 504 and did not need to be provided).

7034 C.F.R. § 104.25(a) (2012). 
meaning of the evaluation data, and the placement options. ${ }^{71}$ Before rejecting placement at the assigned school, the head of the public entity must decide that compliance would result in a fundamental alteration or undue burden, and that decision must be made after considering all resources available for use in the funding and operation of the service, program, or activity and must be accompanied by a written statement of the reasons for reaching that conclusion. $^{72}$

An argument can be made that charter schools can never deny admission to a student and provide FAPE off-site but instead must create programs to accommodate all students on-site. The Department of Education states that the newly assigned school must be "comparable" to the school where the student was denied admission. $^{73}$ Because of the uniqueness of charter schools, it has been argued, there are no "comparable" placements. ${ }^{74}$ But each school is unique for at least its location and student body makeup, which can often be more important to parents and students than the curriculum or teaching method. The emphasis on undue burden and fundamental alteration - rather than program uniqueness - should not change simply because charter schools are involved. ${ }^{75}$

7134 C.F.R. $\S 104.35(c)(2012)$.

72 This requirement is not found in Subpart B of Section 504, which contains only a FAPE requirement, but it is found in Part 35 interpreting the ADA in state and local government services. See 35 C.F.R. $\S \S 35.164$ (2012) (regarding communications), 35.150 (regarding program accessibility).

${ }^{73}$ U.S. DEP'T OF EDUC., OFFICE FOR CIVIL RIGHTS, APPLYING FEDERAL Civil Rights LAWs TO PUBlic CHARTER Schools 17 (2000), available at http://www2.ed.gov/offices/OCR/archives/pdf/charter.pdf; 34 C.F.R. § 104.34(c) (2012) ("If a recipient . . . operates a facility that is identifiable as being for handicapped persons, the recipient shall ensure that the facility and the services and activities provided therein are comparable to the other facilities, services, and activities of the recipient.").

74 See, e.g., Heubert, supra note 10, at 321 n. 98, 332-33, 340; Paul O'Neill, Richard Wenning \& Elizabeth Giovannetti, Serving Students With Disabilities in Charter Schools: Legal Obligations and Policy Options, 169 ED. L. REP. 1, 12-13 (2002); Santa Clara Unified Sch. Dist., 53 InDIVIDUALS WITH DisABILITIES EDUC. L. REP. 27 (OCR 2009) (OCR rejected the position that services do not have to be offered at the particular school because they were offered at other district schools, because "this general principle is applicable ... only with respect to sites that offer the same educational program" and "Millikin is a unique program.").

${ }^{75}$ See Garda, supra note 3, at 704-05. 
At the other extreme, an argument can be made that schools can always deny admission to a disabled student and merely assume legal and financial responsibility for providing a FAPE off-site. Nothing in IDEA or Subpart B of Section 504 expressly limits the right to place students off-site. If the undue burden limitation cannot be implied into Subpart B to limit the FAPE requirement, the argument goes, then a reasonable accommodation requirement demanding services be provided on-site can also not be implied. Cost concerns clearly support this position as schools and districts can accrue significant efficiency savings by clustering students with similar disabilities at one institution instead of creating programs at each institution. But this argument misses the mark because the general equal access and equal opportunity provisions of Section 504 and the ADA are not negated by the off-site FAPE provisions of Section 504. It is the other way around- the off-site FAPE provisions should be limited by the anti-discrimination directives. It is well established that schools and districts cannot have a policy categorically denying admission to students based on their disability or need for additional services. ${ }^{76}$ No school can reject an entire class of disabled students and refer them to another school, meaning that the off-site FAPE provisions are circumscribed. ${ }^{77}$

In sum, charter schools like traditional schools must always provide disabled students a FAPE irrespective of the burden. They may deny admission and provide FAPE off-site only if providing the FAPE on-site would unduly burden or fundamentally alter the nature of the charter school. The critical issue, then, is what constitutes a fundamental alteration or undue financial burden.

7628 C.F.R. $\$ 35.130$ (b)(8) (2012); Guthrie Pub. Sch., 5 EARLY CHILDHOOD LAW \& POL'Y REP. 10 (OCR 2006) (holding that "children with disabilities cannot be categorically excluded from the program and must be offered meaningful access to the program."); Raytown C-2 Sch. Dist., 53 InDIVIDUALS WITH DisABILITIES EDUC. L. REP. 239 (OCR 2009) (same); Santa Clara Unified Sch. Dist., 53 Individuals with Disabilities EduC. L. ReP. 27 (OCR 2009) (same).

${ }^{77}$ Requirements Under Section 504, supra note 59. 


\section{B. Fundamental Alterations and Undue Burdens in Schools}

Courts, hearing officers, and the OCR have had many occasions to determine what constitutes an undue financial burden or a fundamental alteration to a program, but rarely in the context of deciding what services must be provided on-site by public primary and secondary schools. ${ }^{78}$ The next section focuses on decisions that discuss the fundamental alteration and undue burden requirements in the school context.

\section{Undue Financial Burden}

OCR defines an undue burden as "an action requiring significant difficulty or expense or one that is unduly costly, extensive, substantial, or disruptive."79 The Supreme Court, in the employment context, has held that the undue hardship inquiry

requires not simply an assessment of the cost of the accommodation in relation to the recipient's overall budget, but a 'case-by-case analysis weighing factors that include: (1) the overall size of the recipient's program with respect to number of employees, number and type of facilities, and size of budget; (2) the type of the recipient's operation, including the composition and structure of the recipient's

${ }^{78}$ See, e.g., Sch. Bd. of Nassau Cnty. v. Arline, 480 U.S. 273, 287 n. 17 (1987) (holding in the employment context that accommodations are not reasonable if they impose "undue financial and administrative burdens" or if they require a "fundamental alteration in the nature of a program.") (citations omitted); Se. Cmty. Coll. v. Davis, 442 U.S. 397, 412 (1979) (holding in the higher education context that accommodations are not reasonable if they impose undue financial and administrative burdens); Olmstead v. L.C. ex rel. Zimring, 527 U.S. 581 (1999) (applying fundamental alteration and undue financial burden test in the context of state mental health system).

${ }^{79}$ Glendale Unified Sch. Dist., 4 EARLY CHILDHOOD LAW \& POL'Y REP. 101 (OCR 1988). The undue burden standard requires a showing that "the cost of additional supervision is so great that it would cause the program to collapse financially or become prohibitively expensive for many of its current participants." Id. 
workforce; and (3) the nature and cost of the accommodations needed. ${ }^{, 80}$

Application of this standard is inconsistent depending on the educational setting in which it is applied. In academic programs within public schools, OCR applies a high standard. Of the cases reviewed, OCR has never excused a school or district from providing a service because its provision was unduly burdensome. ${ }^{81}$ The sample size is small because, as explained above, of the significant confusion over whether, and how, the undue burden "limitation" applies to the academic programs in public schools. ${ }^{82}$ Based on the small sample, though, it appears that charter schools will have a difficult time refusing to provide services on-site because of an undue financial burden.

In the non-academic context, the undue burden hurdle is slightly less stringent. ${ }^{83}$ For example, in Timothy H. ex rel. Kratisha H. v. Cedar Rapids Community School District, the Eighth Circuit held that spending $\$ 24,000$ on a special bus route to allow a disabled child to attend a non-neighborhood school as part of an intra-district

${ }^{80}$ Olmstead, 527 U.S. at 608 n. 16 (relying upon 28 C.F.R. $\S 42.511$ (c) (dealing with nondiscrimination in employment context)). See also 28 C.F.R. $\S$ 36.104 (2012) (defining "undue burden" in public accommodation context).

${ }^{81}$ See Santa Clara Unified Sch. Dist., 53 InDIVIDUALS WITH DisABILITIES EDUC. L. REP. 27 (OCR 2009) (OCR rejected argument that it would be unduly burdensome to provide special education services because the district failed to present any evidence of costs or how or why that cost would unduly burden the district); Ripon Unified Sch. Dist., 46 IndividuAls WITH DisABILITIES EDUC. L. REP. 82 (OCR 2006) (holding that use of behavior intervention strategies, that were part of child's IEP, in aftercare program and changing general discipline policies did not fundamentally alter the program); Mystic Valley Reg'l Charter Sch., 40 INDIVIDUALS WITH DisABILITIES EDUC. L. REP. 275 (Mass. SEA 2004) (holding that in-class ban on peanuts, provision of safe food substitutes, staff training and in place emergency protocols were not undue burdens to accommodate a child with a life threatening peanut allergy); Tewskbury Public Sch., 17 INDIVIDUALS WITH DisABILITIES EDUC. L. REP. 1221 (Mass. SEA 1991) (structural modifications and additional staff were not an undue financial burden to a public hospital school, despite being costly, in part because the services would have also benefited nine other students).

${ }^{82}$ See supra Part III.A.

83 Bellevue Sch. Dist. No. 405, 4 EARly ChILdHOOd LAW \& POL'y REP. 136 (OCR 1999) (noting different standards that apply to academic and nonacademic programs and activities). 
transfer program was an undue financial burden. ${ }^{84}$ And in McDavid v. Arthur, the court held that the provision of glucagon-trained staff at all times in after-school and summer programs would "self evidently" impose an undue financial burden. ${ }^{85}$ Neither court discussed the cost of the service compared to the recipient's overall budget or any of the factors identified by the Supreme Court in their analysis. These two cases are rare exceptions to the typical holding that requested accommodations do not impose undue financial burdens. ${ }^{86}$ For example, in Broward County School District, OCR found that hiring a one-on-one aide was not an undue financial burden on an aftercare program, despite the program being in the red, because it considered all the District's resources for aftercare programs. $^{87}$ Numerous cases reach similar conclusions. ${ }^{88}$

${ }^{84} 178$ F.3d 968, 973 (8th Cir. 1999).

85437 F. Supp. 2d 425, 429 (D. Md. 2006).

${ }^{86}$ See also Cascade Sch. Dist., 37 InDIVIDUALS WITH DisABILITIES EDUC. L. REP. 300 (Or. SEA 2002) (holding that it was an undue administrative burden to require a school to prohibit distribution of any food that may contain peanuts when it came to non-mandatory extracurricular events because it would require district to police behavior of participants, parents and community members).

8744 IndiVIDUALS WITH DisABILITIES EDUC. L. REP. 66 (OCR 2005).

${ }^{88}$ See, e.g., AP ex rel. Peterson v. Anoka-Hennepin Indep. Sch. Dist. No. 11, 538 F. Supp. 2d 1125, 1142 (D. Minn. 2008) (holding that provision of a nurse trained to administer a blood-glucose meter and insulin pump in a daycare setting would probably not be an undue financial burden); Raytown C-2 Sch. Dist., 53 INDIVIDUALS WITH DisABILITIES EDUC. L. REP. 239 (OCR 2009) (holding that providing 1:1 aide for autistic child did not unduly burden aftercare program); Chattahoochee Cnty. Sch. Dist., 6 EARLY CHILDHOOD LAW \& POL'Y REP. 26 (OCR 2008) (holding that provision of $1: 1$ aide for child with cerebral palsy did not unduly burden after school childcare program because the $\$ 48 /$ day cost was small compared to entire operating budget of program); Guthrie Pub. Sch., 5 EARLY CHILDHOOD LAW \& POL'Y REP. 10 (OCR 2006) (holding that mere fact that additional personnel would have to be hired in aftercare to accommodate child's unpredictable and disruptive behavior program was not an undue burden); Murrieta Valley Unified Sch. Dist., 44 IndividuALS WITH DisABILITIES EDUC. L. REP. 12 (OCR 2005) (holding that training staff to implement a behavior modification plan would not be an undue burden because costs are minimal); Mentor Exempted Vill., 32 INDIVIDUALS WITH DisABILITIES EDUC. L. REP. 243 (OCR 2000) (provision of $1: 1$ aide in summer program for severely autistic child was not an undue burden because cost could be absorbed by all children in the program for a minimal cost); Cherry Creek Sch. Dist. \#5, 3 EARLY CHILdHOOD LAW \& POL'Y REP. 184 (OCR 1997) (holding that provision of $1: 1$ aide in summer program was not an undue financial burden despite minimal profit margin, no ending balance, and director 
The undue burden limitation is most liberally applied in the "public accommodation" context, such as private schools. For example, in Hunt v. St. Peter School, ${ }^{89}$ the court held:

[A] mandatory [scent free environment] policy would be burdensome, indeed unworkable. St. Peter has an unusually small administrative staff, one principal and a part-time secretary for nearly 500 students in eight grades. It does not have a full-time nurse but relies upon a public health nurse who comes occasionally . . . . It would be unreasonable to require the school to enforce a scent-free policy under these circumstances. ${ }^{90}$

Courts find accommodations are not unduly burdensome to private schools only when they are minimal in cost, such as teacher training ${ }^{91}$ or creating and abiding by a specialized schedule. ${ }^{92}$

Several lessons for charter schools can be drawn from these cases. First, charter schools face a high burden in refusing to provide services on-site and denying disabled students admission on the

was not paid for her work for one year); Conejo Valley Unified Sch. Dist., 23 INDIVIDUALS WITH DISABILITIES EDUC. L. REP. 448 (OCR 1995) (holding that hiring a part time aide at $\$ 8-10 /$ hour for an aftercare program was not an undue financial burden for a program that was able to raise sufficient funds in one year to pay $\$ 80,000$ of an outstanding debt).

89963 F. Supp. 843 (W.D. Mo. 1997).

${ }^{90} \mathrm{Id}$. at 852 . See also Roberts v. KinderCare Learning Ctrs., Inc., 86 F.3d 844, 925-27 (8th Cir. 1996) (holding that the provision of 1:1 aide was an undue financial burden because the wages paid the aide were double the revenue the private daycare earned in tuition from the disabled student); D.R. v. Antelope Valley Union High Sch. Dist., 746 F. Supp. 2d 1132, 1132 (C.D. Cal. 2010) (holding that it was unduly burdensome for a private school to provide a student with serious disciplinary problems individual therapy because it does not normally provide such therapy, and apparently is neither equipped nor qualified to do so).

${ }^{91}$ Alvarez ex rel. Alvarez v. Fountainhead, Inc., 55 F. Supp. 2d 1048, 1054 (N.D. Cal. 1999) (requiring private preschool teachers to undergo training to recognize symptoms of wheezing and assist in administering an inhaler was not an undue financial burden because the training was free and the student offered to sign a liability waiver).

${ }^{92}$ Burriola v. Greater Toledo YMCA, 133 F. Supp. 2d 1034, 1039 (N.D. Ohio 2001) (holding that supplies to make a child-specific schedule and time and effort to make schedule were not undue financial burdens). 
grounds that the cost is unduly burdensome. The stringent application of the undue burden standard to academic programs comports with the nondiscrimination principles of access and opportunity that are comparable to non-disabled students.

Second, the legal status of the charter as an independent LEA or part of an LEA impacts the undue burden analysis. On the one hand, charter schools that are part of a LEA will have a harder time establishing an undue burden than independent charter schools because the overall budget considered in the analysis is that of the entire LEA. For independent charter schools, its smaller budget, resources, and personnel make it easier to establish an undue burden than a charter school in a district with more resources. On the other hand, charter schools that are part of a LEA and deny admission in order to cluster students with particular disabilities at a regional program within the LEA may be subject to a lower undue burden standard. Courts employ a more lenient standard-one of resource allocation efficiency - when holding that students do not have a right to attend a particular school within a LEA. ${ }^{93}$ But, no matter the legal status, the burden of establishing financial hardship is still steep.

\section{Fundamental Alteration}

A fundamental alteration is one that requires a change in the essential nature of services being offered. ${ }^{94}$ In the most recent Supreme Court case on this issue, the Court held that allowing a professional golfer to use a cart during PGA tour events did not fundamentally alter the game of professional golf because " $[\mathrm{t}]$ he use of carts is not inconsistent with the fundamental character of golf, the essence of which has always been shotmaking." 95 The critical inquiry, therefore, is determining the essential nature of the school program.

\footnotetext{
93 See supra note 63 and accompanying text; Garda, supra note 3, at 677-
} 79,705

${ }^{94}$ PGA Tour, Inc. v. Martin, 532 U.S. 661, 682 (2001); Glendale Unified Sch. Dist., 4 EARly ChILdHOOd LAW \& POL'Y ReP. 101 (OCR 1988). For a general discussion of the fundamental alteration defense, see Kerri Lynn Stone, The Politics of Difference and Inclusion: Toward a Uniform Framework for the Analysis of "Fundamental Alteration" Under the ADA, 58 HASTINGS L.J. 1241 (2007) (summarizing cases applying fundamental alteration defense).

${ }^{95}$ Martin, 532 U.S. at 663. 
This analysis was quite simple in Montalvo v. Radcliffe, ${ }^{96}$ where a child with HIV requested that a private karate academy make its instructional style less physically combative to ensure no blood was drawn. ${ }^{97}$ The Fourth Circuit held that " $[\mathrm{t}] \mathrm{o}$ require U.S.A. Bushidokan to make its program a less combat-oriented, interactive, contact intensive version of karate would constitute a fundamental alteration of the nature of its program. The ADA does not require U.S.A Bushidokan to abandon its essential mission and to offer a fundamentally different program of instruction." 98

But in the public school context, particularly public schools with a unique curriculum, the analysis becomes more difficult. In Santa Clara Unified School District, ${ }^{99}$ the Millikin Basics+ Elementary School denied admission to disabled students requiring a resource specialist program because the resource specialist program fundamentally altered the group instructional model utilized at the school. ${ }^{100}$ OCR rejected this argument because some students with disabilities could benefit from group instruction. "The fact that a student may need some form of special education does not [sic] per se establish that his or her participation would [sic] require a fundamental alteration of the program."101 In addition, OCR noted that the school already provided pull-out services such as counseling and English language learning. ${ }^{102}$ The essence of the school was not group instruction in all circumstances, and even if it were, some disabled students could benefit from the methodology, and a categorical ban was discriminatory. Similar conclusions are routinely reached in the academic context; and, of the cases

96167 F.3d 873 (4th Cir. 1999).

${ }^{97}$ Id. at 875 .

${ }^{98}$ Id. at 879. See also Bercovitch v. Baldwin Sch., Inc., 133 F.3d 141, 152 (5th Cir. 1998) (holding that "the normal progressive discipline built into the school's code was . . . effectively enjoined from suspending Jason, as it would any other student, for repeated disruptive behavior. This was an alteration of a fundamental requirement of the school's academic program and as such is not required by the ADA.").

9953 INDIVIDUALS WITH DisABILITIES EDUC. L. REP. 27 (OCR 2009).

${ }^{100} I d$.

${ }^{101} I d$.

${ }^{102} I d$. 
reviewed, only one upheld denial of service because it fundamentally altered the program. ${ }^{103}$

Even in the non-academic services context, the fundamental alteration limitation is strictly applied. A fundamental alteration is typically found only when the student, even with accommodation, cannot participate in a majority of the program. In Mentor Exempted Village, the OCR found that provision of a one-on-one aide for an autistic child in a summer program did not fundamentally alter the program merely because it changed the staff-child ratio. But the OCR allowed the summer program to deny admission to the student because, even with the aide, the child would be unable to participate in field trips, which accounted for sixty percent of the activities and would have to be given alternative care.

A fundamental alteration can also be found when the only effective accommodation changes the essence of the program. The OCR permitted the Bellevue School District to exclude a disruptive

103 Timothy H. v. Cedar Rapids Cmty Sch. Dist., 178 F.3d 968, 973 (8th Cir. 1999) (finding that "requiring the school district to spend any amount of money to provide transportation to students participating in its intra-district transfer program would fundamentally alter the main requirement of the program designed to be of no cost to the school district-parental transportation."). But see D.R. v. Antelope Valley Union High Sch. Dist., 746 F. Supp. 2d 1132, 1148 (C.D. Cal. 2010) (finding that provision of elevator key did not fundamentally alter nature of program); C.C. ex rel. Ciriacks v. Cypress Sch. Dist., 56 InDIVIDUALS WITH DisABILITIES EDUC. L. REP. 295 (C.D. Cal. 2011) (holding that caring for service dog and training teachers several commands for dog did not fundamentally alter public autism program because program changes would be minor); Tewskbury Public Sch., 17 Individuals WiTH DisABILITIES EDUC. L. REP. 1221 (Mass. SEA 1991) (holding that "[g]iven the Hospital School's dual status as a hospital and a specialized school for [disabled students] the [additional professional services] sought by Christopher do not require a fundamental alteration in the nature of the program.'); Mystic Valley Reg'l Charter Sch., 40 InDIVIDUALS WITH DisABILITIES EDUC. L. REP. 275 (Mass. SEA 2004) (holding that accommodations such as a classroom peanut ban that impacted other students did not fundamentally alter the educational program).

104 Mentor Exempted Vill., 32 Individuals with DisABILITIES EDUC. L. REP. 243 (OCR 2000). See also Cherry Creek Sch. Dist. \#5, 3 EARLY CHILdHOOd LAW \& POL'Y REP. 184 (OCR 1997) (holding that admitting student with severe ADHD would fundamentally alter summer program because it would reduce the adult-child ratio, it would not be able to permit the child to attend most field trips and excursions which make up most of the program and it would have to provide an effective setting for the student's removal from the group at the school). 
and physically dangerous child from an after-school child care program because the only accommodation to address his behavior was reducing the number of children in the program and the "essential nature [of the program] was to provide a safe environment for a large group of children to engage in supervised, unstructured activities ...."105 The provision of one-on-one aides or additional supervision is rarely found to be a fundamental alteration of the program because "the provision of extra supervision and services does not fundamentally alter the nature of a program designed to provide supervision for children ....."106 In addition, minor adjustments, such as implementing behavior plans and providing

105 Bellevue Sch. Dist., 4 EARly ChILdhoOd LAW \& POL'y ReP. 136 (OCR 1999). See also McDavid v. Arthur, 437 F. Supp. 2d 425, 429 (D. Md. 2006) (holding, without any analysis, that provision of glucagon trained staff at all times in after school and summer program would fundamentally alter the nature of the program).

106 Raytown C-2 Sch. Dist., 53 InDividuAls with DisABILITIES EDUC. L. REP. 239 (OCR 2009). See also Chattahoochee Cnty. Sch. Dist., 6 EARLY CHILDHOOD LAW \& POL'Y REP. 26 (OCR 2008) (holding that provision of extra supervision for child with cerebral palsy did not fundamentally alter after school childcare program); Glendale Unified Sch. Dist., 4 EARLY CHILDHOOD LAW \& POL'Y REP. 101 (OCR 1988) (holding that provision of 1:1 aide in before and after school program did not fundamentally alter program because "the essence of the CD Program is to provide supervision to children. What disabled children may require is more of such supervision [therefore] it does not change the program."); Broward County Sch. Dist., 4 EARly ChILdHOOD LAW \& POL'y REP. 139 (OCR 1999) (holding that provision of $1: 1$ aide for after-school care did not fundamentally alter the program); Orr ex rel. Huffstutler v. KinderCare Learning Ctrs., 23 Individuals WiTh Disabilities EduC. L. ReP. 181 (E.D. Cal. 1995) (holding that personal services needed by child with mental retardation, low vision and mild seizures did not fundamentally alter private daycare program because "providing these personal services to children under three years of age is part of Kindercare's normal program, plaintiffs have made a strong showing that it is a reasonable modification, but not a fundamental alteration, for Kindercare to provide these services to an older child like Jeremy who needs the services, not because of his age but because of his disability."); Burriola v. Greater Toledo YMCA, 133 F. Supp. 2d 1034, 1038 (N.D. Ohio 2001) (holding that provision of one-on-one attention at private group daycare facility and creating schedule for an autistic child did not fundamentally alter program because even in group daycare setting teachers are required to provide one-on-one attention to students and an autistic child in the program already had a 1:1 aide). But see Roberts v. KinderCare Learning Ctrs., Inc., 86 F.3d 844, 925-26 (8th Cir. 1996) (holding that provision of 1:1 aide fundamentally altered private daycare center services without any analysis). 
nursing services, are also not fundamental alterations to nonacademic programs. ${ }^{107}$

Charter schools can draw several lessons from the above cases. First, no school can categorically exclude all disabled students or categories of disabled students on the grounds that those students would change the essential character of the school. Each child must be looked at individually, and it cannot be assumed that accommodating any particular disabling condition would require a fundamental alteration. For example, a charter school that utilizes a Waldorf or Montessori method which relies primarily on guided free play and self-directed learning cannot categorically exclude autistic students simply because those students typically need a highlystructured and directed education. Instead, the school must look at the unique needs of each individual child to see if he or she could benefit from a majority of the program with accommodation. Second, the more unique the curriculum or teaching method, the more likely a fundamental alteration can be established. It would be easier for the hypothetical Waldorf or Montessori charter school to deny admission to an autistic child because he or she could not participate in the guided free play or self-directed learning than a charter school utilizing more traditional teaching methods. The more vanilla the teaching method or curriculum, the less likely there will be a fundamental alteration.

Even with a unique methodology or curriculum, the burden will still be high to establish a fundamental alteration. The school would either need to show that, even with accommodations, the child could not participate in a majority of the program (i.e. the autistic

${ }^{107}$ Murrieta Valley Unified Sch. Dist., 44 INDIVIDUALS WITH DiSABILITIES EDUC. L. REP. 12 (OCR 2005) (holding that training for, and implementation of, behavior plan was not a fundamental alteration of an after school childcare program); Mukilteo Sch. Dist. No. 6, 51 INDIVIDUALS WITH DiSABILITIES EDUC. L. REP. 85 (OCR 2008) (holding that using student aide to open doors and help mobility impaired students up ramps did not fundamentally alter a summer vocational school program); Alachua County Sch. Dist., 52 InDIVIDUALS WITH DisABILITIES EDUC. L. REP. 204 (OCR 2009) (holding that providing assistance for student with colostomy bag did not fundamentally alter after-school enrichment program); Alvarez ex rel. Alvarez v. Fountainhead, Inc., 55 F. Supp. 2d 1048, 1052 (N.D. Cal. 1999) (requiring private preschool teachers to recognize symptoms of wheezing and assist in administering an inhaler was not a fundamental alteration because "teachers are not being asked to engage in a function that is wholly different from those duties already being performed for other children"). 
child would be in a resource room for more than half the day in the Montessori school) or that the only effective accommodation would change the essence of the program (i.e. the only effective modification to the Montessori method for the autistic child would be to eliminate guided free play).

\section{CONCLUSION}

The simple conclusion that access rights of disabled students to charter schools are the same as their access rights to traditional schools masks several complicating factors. First, the access rights of disabled students to traditional schools are far from settled. The statutes, regulations, and jurisprudence do not clearly indicate when a school must provide a FAPE on-site and when it can fulfill that responsibility off-site at another school or in another district/LEA. IDEA is founded on the "zero-reject" principle but expressly allows schools and districts to provide FAPE outside the district or school. Section 504 demands equal access, but allows schools and districts to provide FAPE off-site, apparently without limitation. Title II of the ADA also provides for equal access, but includes a fundamental alteration and undue burden limitation - a limitation apparently not imposed under Section 504. Finally, courts allow schools and districts to provide FAPE off-site but only in undefined circumstances. The only way to make sense of these competing principles and directives is to require schools, both traditional and charter, to (1) be financially and legally responsible for FAPE under all circumstances, and (2) provide FAPE on-site unless it can establish, through proper procedures, that it is unduly burdensome or fundamentally alters the nature of the program.

The second confusing factor is that some charter schools exist as part of LEAs whereas others are their own, one-school LEAs. Section 504 and the ADA, applying to recipients of federal funding and public entities, respectively, draw no distinction in the obligations between independent and dependent LEAs. IDEA, however, places the locus of responsibility on the LEA and not individual schools, apparently making it more permissive of off-site placement for charters that are part of LEAs. On the other hand, the more limited budgets and resources of independent charter schools means the undue burden hurdle is easier to overcome than for charters that are part of a larger LEA. It is difficult, if not 
impossible, to resolve this conundrum under the law as written.

The final complicating factor is the uniqueness of charter schools compared to traditional schools. Because many charter schools utilize unique curricula and teaching methods, the duty to provide a "comparable" off-site setting under Section 504 and the ADA seems to present a bigger hurdle for charters to overcome when denying admission in lieu of placement at another school than that faced by traditional schools. But uniqueness should not be the guiding principle in determining on-site and off-site placement, because each school is unique for at least its location and student body composition. Instead, the focus should remain on whether the needed services create an undue burden or fundamental alteration, a burden more likely met by an independent charter with few resources and a unique curriculum and teaching method. 